\title{
Rapidly progressive, large nascent cervical myoma with intrauterine device - case report and review of literature
}

\section{Gwałtownie rosnący, duży, rodzący się mięśniak szyjkowy z wkładką domaciczna - opis przypadku i przegląd piśmiennictwa}

\author{
Marek Sikorski \\ Department of Perinatology and Gynecological-Obstetrical Nursing, Institute of Nursing and Obstetrics, Faculty of Medicine and Health \\ Science, Jan Kochanowski University, Kielce, Poland \\ Head of the Department: Prof. UJK Marek Sikorski MD, PhD
}

Medical Studies/Studia Medyczne 2017; 33 (1): 51-54 DOI: https://doi.org/10.5114/ms.2017.66958

Key words: myoma nascens, uterine cervix, spectral Doppler velocimetry.

Słowa kluczowe: mięśniak rodzący się, szyjka macicy, Doppler spektralny.

\begin{abstract}
This report presents the case of a 38-year-old woman with an uncomplicated intrauterine device in the uterine cavity diagnosed with a rapidly progressing, nascent myoma of cervical origin, finally managed by abdominal hysterectomy. The observation is unique due to the demonstration of a rapid tumour growth pace in a 2-year interval, documented by transvaginal ultrasound scans, evolution of its vascularisation with a consistent high resistance index measured by spectral Doppler, unusual (cervical) primary location with no myometrial cells shedding during the aspiration biopsy, nascent character behaviour while being non-pedunculated, coexistence with an intrauterine device, and the approach to definite clinical management after failure of the attempt to perform a vaginal myomectomy. The study points out obstacles in obtaining reassurance of a benign character of rapidly progressing tumours of mesenchymal origin before surgery.
\end{abstract}

\section{Streszczenie}

W pracy przedstawiono przypadek 38-letniej pacjentki z wewnątrzmaciczną wkładką antykoncepcyjną, u której rozpoznano gwałtownie rosnącego mięśniaka gładkokomórkowego wychodzącego ze ściany szyjki macicy i rodzącego się dopochwowo. Z tego powodu u kobiety wykonano brzuszne usunięcie macicy. Przypadek jest nietypowy ze względu na pełną dokumentację ultrasonograficzną gwałtownego wzrostu guza w ciągu 2 lat, obserwacje jego waskularyzacji z utrzymującymi się wysokimi wartościami wskaźnika oporu przepływu naczyniowego, skrajnie rzadko występującą pierwotną lokalizację mięśniaka (szyjkowa), brak komórek mięśniaka w biopsji aspiracyjnej kanału szyjki, rodzenie się przez ujście zewnętrzne kanału szyjki pomimo braku szypuły, współwystępowanie z wewnątrzmaciczną wkładką antykoncepcyjną oraz ostateczny zabieg chirurgiczny. Doniesienie wskazuje na trudności w jednoznacznym określeniu potencjału onkologicznego gwałtownie rosnących guzów pochodzenia mezenchymalnego.

\section{Introduction}

A monoclonal focal proliferation of uterine muscle tissue frequently leads to the formation of benign tumours - myomas (fibroids). Their influence on women's quality of life and on secondary complications depends significantly on the location in the uterine wall and on their biological behaviour (mainly the pace of progression). The formation of oestrogen/ progesterone-dependent uterine fibroids is common and the typical clinical approach is well described; however, some bizarre cases must cause an increased awareness, particularly concerning a fibroid origin site, final location, the rapidity of growth, and forced modification of treatment.

\section{Case report}

Herein we describe a woman, 38 years old, after two vaginal births, who was admitted to the ambulatory office at GENIX Medical Centre Lublin, Poland twice: on 7.08.2014 and 7.07.2016. At her first admission no major complaints were noted, apart from occasional contact bleeding and sporadic lower abdominal pain preceding menstruation. A copper intrauterine device was inserted 13 months prior to the first admission, and its position in the uterine cavity was proper at the time of an ultrasound examination (above the internal cervical os, $4 \mathrm{~mm}$ to the fundus of the uterine cavity and lateral parts opened); threads of about $2 \mathrm{~cm}$ were protruding from the external os. 

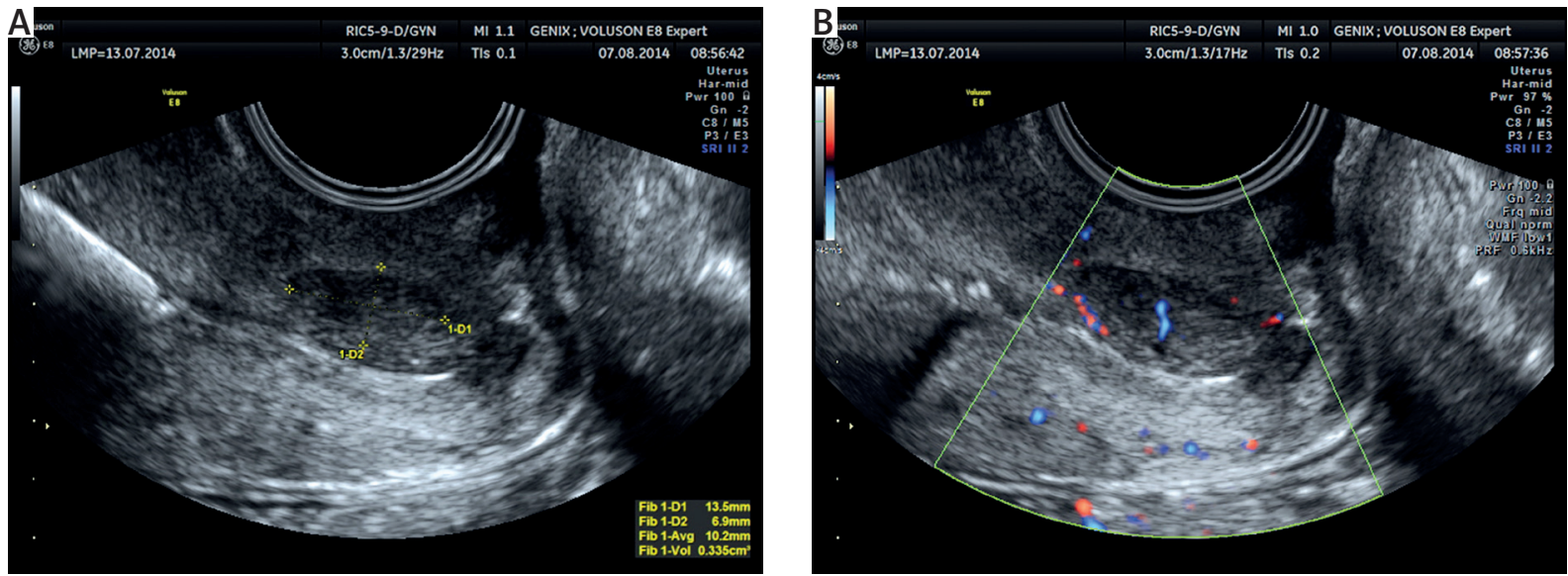

Figure 1. Initial ultrasound scan of intracervical myoma and its vascularisation

A colposcopic examination did not reveal suspected areas on the cervical portio. An ultrasound sagittal scan displayed, however, a solid mass of $13.5 \times 6.9 \mathrm{~mm}$ with a volume of ca. $0.4 \mathrm{ml}$, located in the cervical canal and growing from the anterior part of the cervical wall. The tumour was located $12 \mathrm{~mm}$ proximally from the external os and $15 \mathrm{~mm}$ distally from the internal cervical os. No apparent peduncle was visible. A power Doppler examination revealed moderate energy of blood flow, and the spectral Doppler measurement showed the lowest resistance index of 0.52 (Figure 1). Instant curettage of the cervical canal was performed, yielding only endocervical glandular cells with no morphological abnormalities. The diagnosis was un-

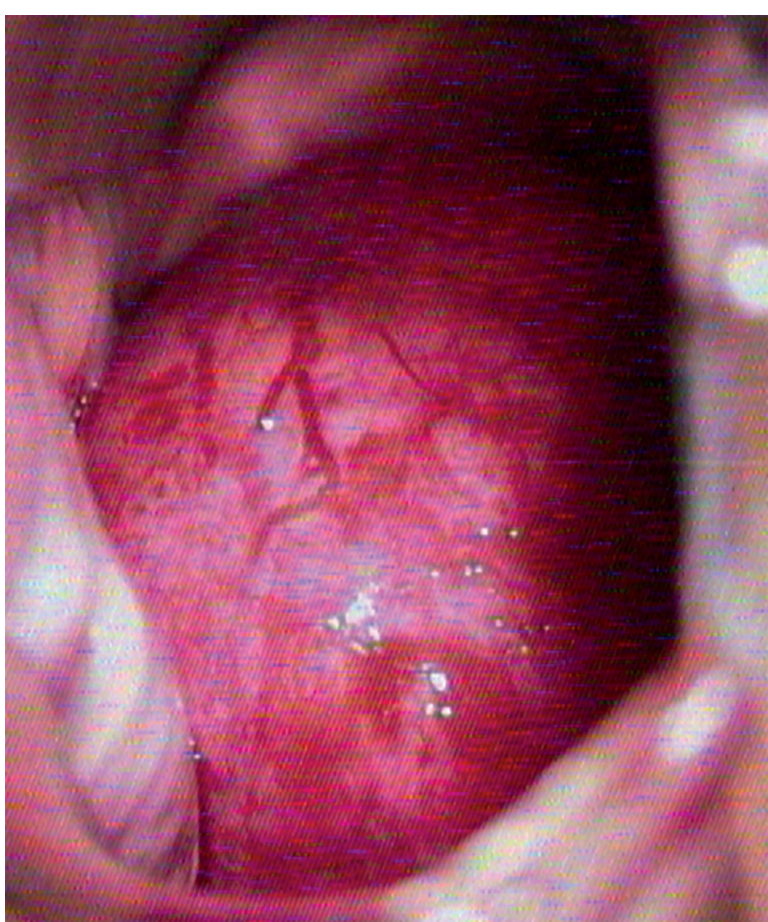

Figure 2. Colposcopic appearance of nascent myoma certain: a cervical myoma or a cervical polyp. Due to lack of severe complaints and clinical symptoms the patient was advised to call after 6 months, with antifibrinolytic therapy only.

However, her next visit was delayed and she was admitted 23 months after the first visit. On this occasion, she complained of increasing cramping pains in the lower abdomen, regular contact bleedings, and heavy menstrual bleedings. A gynaecological examination revealed a largely dilated cervical os with a solid mass of plain surface extruding partially from the os, about $2.5 \mathrm{~cm}$ in diameter. A colposcopic examination demonstrated large vessels of a bizarre pattern on the surface of the tumour, with no signs of neither acetowhite areas or glandular appearance (Figure 2). An ultrasound sagittal scan showed the solid tumour of $33.9 \times 23.1 \mathrm{~mm}$ dimensions and approximately $9.4 \mathrm{ml}$ of volume, filling nearly the entire cervical canal and extending beyond the external os, growing from the anterior part of the cervical wall. The volume of the tumour was more than 20 times larger in comparison to the first examination. Again, no peduncle was shown. A power Doppler examination demonstrated high energy of blood flow, whereas spectral Doppler measurements brought the lowest resistance index (RI) of 0.59 (Figure 3). The distance between the proximal pole of the tumour and the upper border of the cervix did not exceed $2 \mathrm{~cm}$. The intrauterine device (IUD) was again in the proper position with no major alterations in comparison to the previous examination. No suspicious findings relating to the endometrial layer were noticed. The patient was urgently referred to the clinical hospital ward. An attempt of vaginal myomectomy or amputation of the cervix was undertaken, but it failed due to heavy bleeding. Hence, the simple hysterectomy and salpingectomy was performed with ovarian sparing. A pathology report of the tumour revealed only leiomyoma tissue. The patient left hospital after five days in a good general condition. 

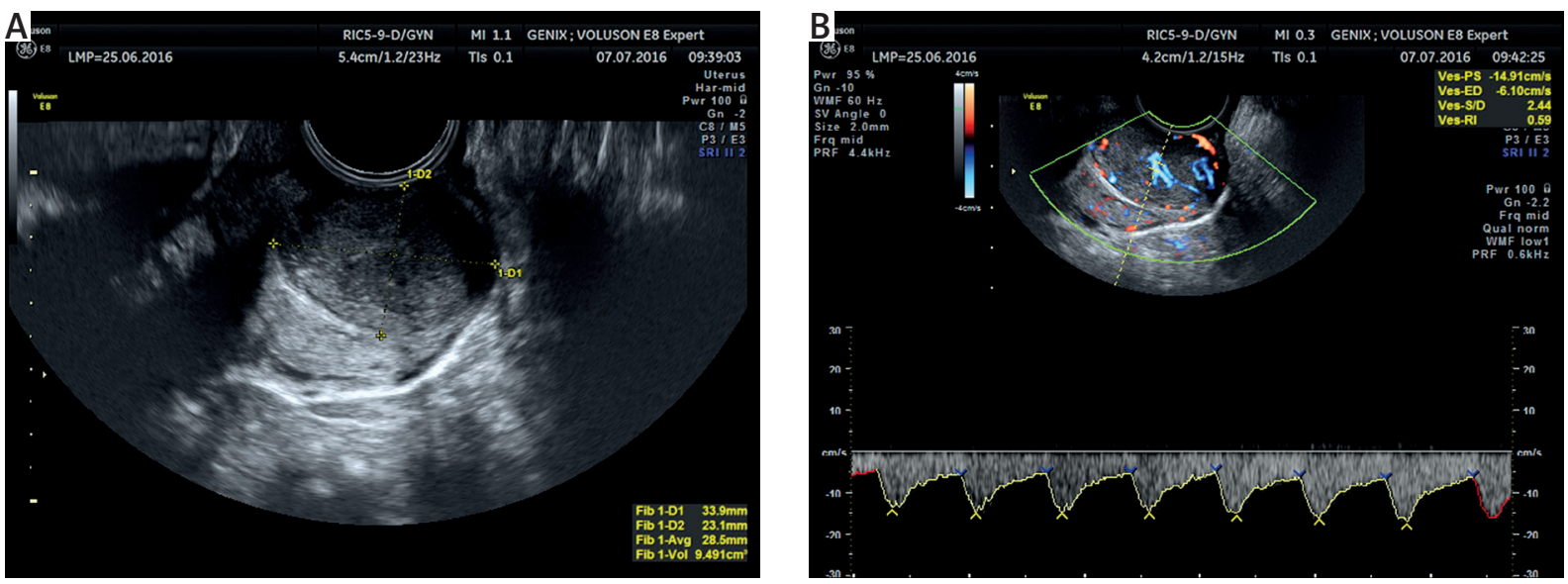

Figure 3. Final ultrasound scan of the cervical myoma nascens and its vascularisation

This case is unique due to several features: rapid growth of myoma with an unusual location and the site of origin, which could be traced along time, a nascens status of the tumour, coexistence with the intrauterine device, and the approach to the final management of the pathology.

\section{Discussion}

Uterine fibroids (leiomyomas) are certainly the most common benign tumours of the female genital tract, with the origin and subsequent location qualified as intramural, subserosal, submucosal, or cervical, the last being probably the least common. In several countries fibroids are the leading cause of hysterectomies in women of reproductive age [1]. The aetiology of a monoclonal proliferation taking place in the fibroid development is largely unknown, although it is multifactorial, with oestrogen and progesterone stimulation driving their progression. The real prevalence of uterine fibroids is difficult to assess (ranges from 5\% to $77 \%$ in different age groups) because many of them might be symptomless and could be detected only occasionally [2]. A large, multinational survey based on self-reported fibroids in non-pregnant women in the age group 40-49 years revealed considerable differences in their prevalence across the countries, from $4.5 \%$ in the United Kingdom to $17.8 \%$ in Italy, as well as across the ethnicity of women [3]. First-trimester ultrasound scans revealed the presence of symptomless fibroids in $8 \%$ to $18 \%$ of pregnant women of white and black ethnicity, respectively [4].

The presence of fibroids is strongly and significantly associated with several typical symptoms such as heavy, prolonged, or frequent menstrual bleedings or bleeding outside of the typical menstrual pattern. Extremely seldom, contact bleeding is reported, which is in contrast to the often mentioned pressure to the bladder or painful intercourse, which significantly worsen women's quality of life.
Pedunculated fibroids protruding to the uterine cavity could be difficult to distinguish from endometrial polyps, or - if they protrude to the cervical canal - from cervical (usually pedunculated) polyps. In certain, rare circumstances the peduncle of the myoma is long enough to enable the extrusion of the tumour through the cervical canal to the vaginal space, finally prolapsing and causing the "delivery" of the fibroid a phenomenon described as myoma nascent. This pattern of fibroid growth could be sporadically observed even in the cervical stump after removal of the uterine body, as the recurrence of the leiomyoma (Sikorski - oral communication). Apart from growing pain, also necrotic changes in the tumour, bleedings, and infections could be associated with a vaginally prolapsed, nascent fibroid, hence the treatment is obligatory. In such an emergent situation the medical (conservative) options could not be considered suitable $(\mathrm{GnRH}$ analogues or antagonists, selective oestrogen receptor modulators, or anti-progesterones), although useful in many other circumstances, particularly as pre-operative treatment [5].

The recommended treatment-of-choice for prolapsed, pedunculated fibroids is a vaginal myomectomy [6]. Although the median diameter of fibroids removed vaginally and described is about $5 \mathrm{~cm}$, some recent reports describing a vaginal myomectomy of tumours exceeding $7 \mathrm{~cm}$ can be found [7]. In our case the attempt to perform the vaginal myomectomy failed due to a large part of the tumour being incorporated into the cervical wall, which caused bleeding at the manipulation. This type of a nascent myoma could be better described as the outgrowth of the tumour from the cervical orifice rather than prolapsing. It appeared to be much safer to perform abdominal hysterectomy, particularly in the case of accomplished parenthood of the patient. Hence, the sonographic evaluation of the volume of the potentially intramural component of the prolapsing fibroid before surgery is 
obligatory to avoid excessive bleeding and failure of the procedure.

The other unique feature of the described case is the rapid growth of the tumour, which could be traced for 23 months. A definitive and fast multiplication of the volume of mesenchymal tumours raises suspicion of their malignant character. The literature on ultrasonographic features that can be useful in assessing the character of the tumour is scarce. Power Doppler semiquantitative assessment of blood flow energy does not bring the conclusive data, in contrast to spectral Doppler measurements of blood flow velocity. The higher mean RI in the arterioles of the examined tumours are shown to be associated with benign structure and were significantly different from those noticed in cases of malignant mixed mesodermal tumours $(0.59 \pm 0.01$ vs. $0.41 \pm 0.18$, respectively) [8]. However, the differences between RI in leiomyomas and leiomyosarcomas were not significant. The lowest RI calculated for our case (0.52-0.59), being above the border of malignancy established for ovarian tumours, served only as a suggestion of benign character of the tumour, but finally turned out to be the correct conclusion. It remained unchanged (over 0.5 ) on both occasions of measurements.

There are several studies conducted to aggregate previous, disseminated observations of features distinguishing malignant and benign mesenchymal tumours, one of them being the PRESS study (Preoperative Sarcoma Score) [9]. Taking into consideration the serum lactate dehydrogenase (LDH) level, magnetic resonance imaging, and endometrial cytology results, the PRESS score appeared to have a high negative predictive value of $93.2 \%$, with a much lower positive predictive value $(63.2 \%)$ in diagnosing uterine sarcomas. Abnormal endometrial cytology results could be suggestive in some cases of sarcomas extending towards the uterine cavity, but this method is far from having a definitive clinical application [10]. In our case, the tumour did not shed cells on intracervical aspirational biopsy, so it could not have been diagnosed conclusively. Therefore, it could have been concluded that a reliable method to separate both types of mesenchymal proliferations is still not available.

Intrauterine devices when positioned in a myomatous uterus tend to dislocate, particularly during menstrual contractions. Here we present a stable position of IUD, despite rapid progression of the fibroid, which was due to the extreme remoteness from the uterine cavity, distally located, focus of myomatous growth.

\section{Conclusions}

Leiomyomas can originate from the cervical wall and outgrow the external cervical os forming the phenomenon of a nascent myoma. In cases of nascent myomas it should be pivotal to preoperatively assess the volume of the intramural portion of the tumour in order to choose the optimal surgery. High spectral Doppler resistance index values in the arterioles of the rapidly growing myoma $(>0.5)$ could be considered only as a suggestion of a benign character of the tumour.

\section{Conflict of interest}

The author declares no conflict of interest.

\section{References}

1. Farquhar CM, Steiner CA. Hysterectomy rates in the United States 1990-1997. Obstet Gynecol 2002; 99: 229-34.

2. Rice KE, Secrist JR, Woodrow EL, Hallock LM, Neal JL. Etiology, diagnosis, and management of uterine leiomyomas. J Midwifery Women's Health 2012; 57: 241-7.

3. Zimmermann A, Bernuit D, Gerlinger C, Schaefers M, Geppert K. Prevalence, symptoms and management of uterine fibroids: an international internet-based survey of 21,746 women. BMC Women's Health 2012; 12: 6 .

4. Laughlin SK, Baird DD, Savitz DA, Herring AH, Hartmann KE. Prevalence of uterine leiomyomas in the first trimester of pregnancy: an ultrasound-screening study. Obstet Gynecol 2009; 113: 630-5.

5. Sabry M, Al-Hendy A. Medical treatment of uterine leiomyoma. Reprod Sci 2012; 19: 339-53.

6. Golan A, Zachalka N, Lurie S, Sagiv R, Glezerman M. Vaginal removal of prolapsed pedunculated submucous myoma: a short, simple, and definitive procedure with minimal morbidity. Arch Gynecol Obstet 2005; 271: 11-3.

7. Terzic M, Maricic $S$, Dotlic J. Vaginal removal of very large nascent uterine myoma - case report and literature review. Geburtshilfe Frauenheilkd 2013; 73: 724-6.

8. Aviram R, Ochshorn Y, Markovitch O, Fishman A, Cohen I, Altaras MM, Tepper R. Uterine sarcomas versus leiomyomas: gray-scale and Doppler sonographic findings. J Clin Ultrasound 2005; 33: 10-3.

9. Nagai T, Takai Y, Akahori T, Ishida H, Hanaoka T, Uotani T, Sato S, Matsunaga S, Baba K, Seki H. Novel uterine sarcoma preoperative diagnosis score predicts the need for surgery in patients presenting with a uterine mass. Springerplus 2014; 3: 678.

10. Oda K, Okada S, Nei T, Shirai T, Takahashi M, Sano Y, Shiromizu K. Cytodiagnostic problems in uterine sarcoma. Analysis according to a novel classification of tumor growth types. Acta Cytol 2004; 48: 181-6.

\section{Address for correspondence:}

Marek Sikorski MD, PhD, Prof. UJK

Department of Perinatology and

Gynaecological-Obstetrical Nursing

Institute of Nursing and Obstetrics

Faculty of Medicine and Health Science

Jan Kochanowski University

al. IX Wieków Kielc 19, 25-317 Kielce, Poland

Phone: +48 6042814 66, +48 817490185

E-mail: marek.sikorski@genix.com.pl 